\title{
MIR551A wt Allele
}

National Cancer Institute

\section{Source}

National Cancer Institute. MIR551A wt Allele. NCI Thesaurus. Code C128930.

Human MIR551A wild-type allele is located in the vicinity of 1 p36.32 and is 96 bases in length. This allele, which encodes MIR551A pre-miRNA, is involved in the negative regulation of gene expression. 